\title{
PSYCHOLOGICAL AND PEDAGOGICAL CONDITIONS OF FORMATION OF FUTURE SPECIALISTS TRAINING IN CONDITIONS OF INCLUSIVE EDUCATION IN INSTITUTIONS OF PROFESSIONAL (PROFESSIONAL AND TECHNICAL) EDUCATION
}

\section{Denkovych N. A.}

\section{INTRODUCTION}

Modern requirements for the formation of professional processes in Ukraine contribute to the creation of innovative approaches and standards in the provision of education and qualification services by institutions of professional (professional and technical) education (hereinafter PTE) in an inclusive environment. Psychological and pedagogical conditions must be formed for successful professional training of future specialists. The legislative base of Ukraine prescribes the main terms and procedures for the organization of inclusive education in PTE institutions.

The Concept of Development of Inclusive Education ${ }^{1}$ states that inclusive education is a comprehensive process of ensuring equal access to quality education for children with special educational needs by organizing their education in secondary schools based on the use of personality-oriented teaching methods, taking into account individual characteristics of educational and cognitive activities of such children.

The Resolution of the Cabinet of Ministers of Ukraine "On Approval of the Procedure for Organizing Inclusive Education in Institutions of Professional (Professional and Technical) Education" ${ }^{2}$ in paragraph 4 states that educational services are provided to students with special educational needs by institutions of professional (professional and technical) education using personality-oriented teaching methods and taking into account the individual characteristics of educational and cognitive activities of such persons.

\footnotetext{
${ }^{1}$ Концепція розвитку інклюзивної освіти : Наказ МОН України від 10.10.2010 № 912. URL: https://mon.gov.ua/ua/npa/pro-zatverdzhennya-kontseptsii-rozvitkuinklyuzivnogo-navchannya (дата звернення: 02.01.2021).

2 Про затвердження Порядку організації інклюзивного навчання у закладах професійної (професійно-технічної) освіти : Постановка КМУ від 20.07.2019 № 636. URL: https://zakon.rada.gov.ua/laws/show/636-2019-\%D0\%BF (дата звернення: 02.01.2021).
} 
The same document states the meaning of terms used in PTE institutions: "students with special educational needs - persons with special educational needs, who receive education in institutions of professional (professional and technical) education; inclusive group - a group in an institution of professional (professional and technical) education, in which, along with other students, one or more persons with special educational needs study.

Paragraph 5 of the same law states the following: "Organization of the educational process of students with special educational needs in institutions of professional (professional and technical) education provides for creation of an inclusive educational environment, psychological and pedagogical support for students with special educational needs".

Inclusive education is based on human rights and the principles of equality; aimed at all children and adults, especially those who are excluded from the general education system; it is a process of removing barriers in the education and support system. Integration in education can solve its main contradictions - the contradiction between the infinity of knowledge and limited human resources. Integration is an organic combination of information from different subjects around one topic, which lays down new conditions for teachers and students, which has a great impact on the effectiveness of their perception of educational material. The main problem of a child with special educational needs is the violation of his connection with the world, limited mobility, lack of contact with peers and adults, limited communication with nature, unavailability of a number of cultural values, and sometimes basic education. The aim of the research is to determine the main psychological and pedagogical conditions for the formation of future specialists training in PTE institution in conditions of inclusive education.

\section{Strategy for the development of inclusion in PTE in Ukraine}

When considering this issue, it should be noted that the training of future specialists often takes place in inclusive groups, where not all applicants have special educational needs. Therefore, there is a need to develop in the professional education institution such a strategy of inclusion, which will be aimed at continuous support and development of all students and adults participants of the educational process. The development strategy designed as a result of such work will allow the educational institution to consider in detail all the ways of overcoming the barriers that stand in the way of obtaining quality professional education for any student of professional education institution. Thus, the strategy for the development of inclusion in PTE institution is not just the sum of some proposals for additional actions and initiatives in relation to students with special educational needs, it should reveal ways to positively change the institution in accordance with inclusive values. These positive changes should not only be an alternative to 
improving student performance, they should help to create effective cooperation between students and teachers of professional education institution. The philosophy of inclusion is based on a social model of understanding disability and an approach based on respect for fundamental human rights. Fundamental to the concept of inclusion is that the individual should not adapt to social and economic relations, but on the contrary society should create conditions to meet the special needs of each individual.

Researcher Z. Leniv ${ }^{3}$ notes that successful psychological and pedagogical conditions during professional training are an intrinsic positive motivation of specialists; optimization of the educational process through deepening, systematization and integration of special knowledge; implementation of personality-oriented interaction in the following systems: "teacher - teacher's assistant - student", "teacher - teacher's assistant - parents", "student teacher's assistant - students' group", "parents - teacher's assistant students"; creating a creative educational space. If such interaction is tested in a PTE institution, we propose to reduce it to the following systems: "teacher psychologist, social pedagogue - student", "teacher - psychologist, social pedagogue - parents" "student - teacher - psychologist, social pedagogue students' group", " parents - teacher / psychologist, social educator students". Creating a creative space at all levels of education for students with special educational needs is one of the main roles.

Taking into account all the above mentioned, it is clear that comprehensive assistance to children with special needs in inclusive education includes: pedagogical assistance, psychological assistance, social assistance. Psychological and pedagogical support of inclusive education and upbringing requires planning, additional professional training, as well as contacts with specialists who can provide appropriate assistance.

The creation of an inclusive environment in the PTE institutions has further led to the professional development of the entire psychological, pedagogical and administrative staff of the educational institution, to the development of their professional training. The activity of a teacher, in connection with modern challenges, has led to its modification and improvement on the basis of innovative pedagogical technologies of teaching and not only inclusive. Psychological and pedagogical cooperation of all participants in the educational process should implement inclusion in the form of teamwork.

Medical care should be outlined separately, as there must be a medical professional in the PTE institution who can provide it. In medicine, certain

3 Ленів 3. П. Формування професійної готовності фахівців до роботи в інклюзивному освітньому просторі початкової школи. Обрії. 2018. № 2(47). C. $57-61$. 
rules regulate the admission of children with disabilities to study certain professions. For example, students with a low threshold of vision, hearing, severe musculoskeletal disorders, mental disorders and more cannot study in the institution with a high level of safety and work with machines. That is why the medical staff begins to get acquainted with the future student of a PTE institution. They study the previous experience of training and conclusion of medical specialists.

The next link that should prepare a student with special educational needs to study in the institution and during all years of study to help him/her is the socio-psychological service of the educational institution. Socio-psychological work with students with special educational needs is aimed at achieving the main goal - to prepare him/her for independent living. This moment is especially important for a PTE institution, because the student is preparing to start his/her independent activity as a professional and qualified specialist who will be competitive in the labor market. However, the social educator makes sure that the help and support during the training does not exceed what is needed, otherwise the student will become too dependent on it. To ensure the overall success of the business, everyone should be treated with respect and work thoughtfully and persistently for the benefit of the student. The social educator promotes the development of students' social skills, as well as provides appropriate moral support to children's families, their relatives and teachers, class teachers and masters of industrial training, helps to overcome difficult life situations. He/she is an expert in conducting both development assessment and prospects for the near future. He/she develops individual and group recommendations, provides psychological support to parents.

The psychologist, in turn, helps to identify factors that negatively affect the ability of teenagers to learn and self-control. Since the development and upbringing of a child with special needs requires special knowledge about the disease, its consequences, the potential of the child, it is important to properly organize the work of a multidisciplinary team of specialists in the school. Parents are given practical advice on child care, explanations and recommendations for solving everyday problems related to education, acquaintance with the experience of other parents. The main forms of group work with parents in this aspect: seminars, consultations, lectures, meetings, and others. At the same time, the interaction is organized in an individual form (individual conversations and individual counseling). At the stage of educational work, a social pedagogue and a psychologist reveal the general problems of mental development of children with special needs. The main task of a PTE institution in working with the family is to make parents see the real prospects for their child's development, to find out possible difficulties of social development that arise in adolescence, as well as to 
determine their role in the process of professional orientation and social pedagogical support of the child.

Achieving the effectiveness of social, psychological and pedagogical activities with children with special educational needs is possible only if tolerance, justice, kindness and respect for people will make an integral part of the educational process. The humane mission of the educational institution and teacher is to save these children, to introduce them to the world of society, spiritual life, and to promote their formation. Class teachers, masters of industrial training, educators, teachers, social pedagogue and practical psychologist work systematically on this task in the PTE institutions.

The main attention in the organization of education and production process in the PTE institution is paid to the individualization of education and a differentiated approach to students. The main goal is to increase motivation for professional training and further employment of children with special needs. When organizing the educational process, the teacher and the master of industrial training must comply with certain requirements. First of all, it is a comprehensive study of the student's anamnesis, understanding of its features, knowledge of patterns of development, study of mental qualities, ability to observe and regulate the student, adaptation of curricula and methods to specific needs of students, using opportunities provided by the variable part of the plan, the nature of students' development, taking into account their personal characteristics, interests and aptitudes, creation of optimal conditions for communication and adaptation to the student environment.

To create successful conditions and individualization, the teaching staff of the institution needs to focus their activities on personality-oriented learning. Personally oriented learning, according to S. Sysoyeva, should take into account the subjective experience, which is the basis for the organization of individual and differentiated learning, it creates conditions for real consideration of the individual pace of learning; introduction of personality-oriented learning provides such professional training of teachers, which includes fundamental training in the subject, thorough psychological and pedagogical training aimed at developing skills for personality-oriented learning, the formation of humanistic thinking, the ability to subjective interaction in the pedagogical process ${ }^{4}$

According to I. Yakymanska ${ }^{5}$, personality-oriented learning is learning, the center of which is the personality of a child, his/her identity, self-worth,

${ }^{4}$ Сисоєва С. О. Особистісно орієнтовані технології: сутність, специфіка, вимоги до проєктування. Професійна освіта: педагогіка і психологія. 2003. № 4. С. 159-160.

Якиманська І. Я. Особистісно-орієнтована система навчання. Завуч. 1999. № 7. C. 22. 
the objective experience of each is first revealed, and then made consistent with the content of education.

The same scientist distinguishes three models of personality-oriented pedagogy: socio-pedagogical, subject-didactic, and psychological.

Socio-pedagogical model educates with predetermined qualities. Educational institutions of society create the structure of such a person. The task of the PTE institution is to bring each student closer to its parameters (carrier of mass culture).

The subject-didactic model of personality-oriented pedagogy is associated with subject differentiation, which provides an individual approach to learning.

The technology of subject differentiation is based on the complexity and volume of educational material (tasks of reduced and increased complexity).

The psychological model of personality-oriented pedagogy was initially reduced to the recognition of differences in the cognitive abilities of students, which in the real educational process are manifested in the ability to learn (individual ability to acquire knowledge). The purpose of the educational process is to correct the ability to learn as a cognitive ability.

Scientists are unanimous in the opinion that the education of people with special educational needs should be personality-oriented, to promote personal development. O. Budnyk ${ }^{6}$ identifies the concept of personality-oriented learning and education in an inclusive process, which aims to identify the subjective experience of students with special educational needs and provide psychological and pedagogical assistance in the formation of his/her individuality, social self-determination and self-realization. We agree with this statement and believe that in order to create conditions for students to ensure rights and opportunities in a person-centered educational environment, all participants in the educational process need to recognize the values and integrity of the student's personality with special educational needs. The process of obtaining education in a PTE institution by a student with special educational needs should be more personality-oriented, teachers' attention should be focused on the capabilities, inclinations and talents of the student, and not on his/her diagnosis. The style and way of learning and perception of information by a student with special needs is individual and personal, so the learning environment of the institution should adapt the learning material according to the specifics of the student and his nosology.

\footnotetext{
${ }^{6}$ Будник О. Б. Педагогічний супровід інклюзивної освіти : навчальний посібник. Івано-Франківськ : Кушнір Г.М., 2019. С. 151.
} 


\section{Professional training of PTE specialists in the conditions of inclusive education}

Competent training of qualified teachers who will be able to work in inclusive groups is important in the professional training of future graduates of the PTE institutions among students with special educational needs, because they have a significant role in preparing a student with special educational needs, adapting him/her to society and as a specialist in the labor market. Providing the educational process with qualified personnel presupposes that teachers are ready to work with children with special needs. As L. Pryadko defines: "they should be teachers who adopt a new system of values, creatively implement new learning technologies, are able to solve the problem of socialization of children with special educational needs, have methods of psychological and pedagogical diagnostics, consistently strive for high results in their professional activities, know the specifics of educational programs, have methods and technologies for teaching children with special educational needs, effectively interact both in the institution and with the surrounding society $" 7$.

According to I. Demchenko, a modern teacher must be exclusively a professional in his/her field and must clearly understand and adequately identify himself/herself with the model of an inclusion specialist. The teacher must have motivation, value traits and tolerance in relations with the subjects of inclusion. The teacher must be responsible for the results of their activities and professional training of the student, as well as be able to humanely solve various pedagogical situations ${ }^{8}$.

In the work of Z. Leniv ${ }^{9}$ the following stages of the system of professional training of specialists capable of working in the conditions of inclusion were developed, which formed the basis of the structural and functional model: I - propaedeutic and motivational; II - content and activity; III - operational and practical.

7 Прядко Л. Готовність педагога загальноосвітнього навчального закладу до роботи 3 дітьми 3 особливими освітніми потребами як успішний фактор інклюзивного навчання. Матеріали Всеукраїнської науково-практичної конференції «Формування готовності педагогічних працівників до роботи 3 дітьми з особливими освітніми потребами в умовах інклюзивного навчання. URL: http://roippo.org.ua/ activities/research/ conferenc.php/376/

8 Демченко I. I. Готовність учителя початкових класів до роботи в умовах інклюзивної освіти: структура та діагностика : навчально-методичний посібник. 2014. $160 \mathrm{c}$.

9 Ленів 3. П. До проблеми моделювання процесу підготовки кадрів для роботи в інклюзивному просторі. Глобальні виклики педагогічної освіти в університетському nросторі : матеріали III Міжнародного конгресу, м. Одеса, 18-21 травня 2017 р. C. $70-81$. 
Each of them has certain characteristics. The author notes that in the first stage there are the following aspects: formation of awareness of the social significance of inclusion; study of the legal framework; argumentation of the need to use knowledge of special psychological and pedagogical disciplines in inclusive pedagogical activities; clarification and specification of the essence of teachers' activity in the conditions of inclusive education. At the second stage, there are the following aspects: mastering of theoretical knowledge by students; formation of ideas about inclusion in action (conditions, implementation mechanisms, pedagogical technologies, monitoring); formation of the ability to organize an inclusive environment and provide a 'universal design', development of the ability to act in a multidisciplinary team of specialists of an inclusive educational institution (team of psychological and pedagogical support). At the third stage, there are the following aspects: formation of the ability to operate with technologies of inclusive education (special methods of invaluable and/or standardized assessment and differentiated teaching, assistance, 'inclusion index'); implementation of modern technical means of communication and training; application of the acquired knowledge and skills in practice; dissemination of theoretical knowledge and practical skills among the educational and parental community.

But in the PTE institutions, the creation of inclusive groups very often occurs in the process of teachers' work in an educational institution. That is why the system of professional training determines the training, which combines the first and second stages and these stages of training often go hand in hand with the third - practical stage, where the teacher with special techniques, adapted programs and technical means of communication and training, forms a lesson plan and the whole course. And that is why the teacher in the PTE institution faces the problem of his/her pedagogical training in an inclusive pedagogical specialty. Although the decree of the Ministry of Education and Science of Ukraine "On Creating Conditions for Ensuring Right to Education of Persons with Disabilities" ${ }^{10}$ provides for the inclusion in the curricula of higher education institutions of III-IV levels of accreditation, training specialists in Pedagogical Education, Fundamentals of Correctional Pedagogy, which provides professional readiness for teaching in an inclusive environment. But mostly this discipline is taught to teachers in general secondary education institutions, not in PTE institutions. And in general, as the experience of other countries shows, for teachers who already

${ }^{10}$ Про створення умов щодо забезпечення права на освіту осіб з інвалідністю : Наказ МОН України від 02.12.2015 № 691. URL: https://ips.ligazakon.net/document/ MUS3912 (дата звернення: 03.01.2021). 
work in the PTE institutions, the best forms of acquiring knowledge are refresher courses, training, and seminars.

An important step for the formation of professional readiness of teachers to work in an inclusive environment is the organization of mentoring for teachers who begin to work in an inclusive classroom. They should work with experienced teachers for at least the first two years. This includes dialogue, consideration of the situation, decision-making and arrangements, work plans. There are three stages that characterize the support and mentoring:

I - intervention. The role of an experienced teacher is directive and leading, dominated by the transfer of information with an emphasis on the explanation and application of knowledge and skills.

II - assistance. The role of an experienced teacher is advisory. His interaction with the beginner is reduced to advice, encouragement and explanation. An experienced teacher provides materials designed for the purpose and facilitates the discussion and consideration of various concepts. An experienced teacher takes on the role of decision coordinator and is an observer. This model focuses on interactive work methodology and improves the quality of action processes.

III - cooperation. An experienced teacher acts as a critical companion or colleague, their relationship is interdependent and is a source of mutual learning, shared responsibility, exchange of experience or perspective. Materials and ideas are developed together.

As mentioned above, a universal design for working in an inclusive environment must be created for the successful perception of the learning material. This term and its definition are stated in the Law of Ukraine "On Education": "Universal design in the field of education - design of subjects, environment, educational programs, and services, which ensures their maximum suitability for the use by all persons without the necessary adaptation or special design"11. Among the main components are the adaptation of curricula, teaching methods and assessment of student achievement. Also, the design of the room: ramps, elevators, the readable font on the ads, bulletin boards at an affordable level, video equipment, and others.

For the successful implementation of such a universal design in an educational institution, there must be a successful manager of a PTE institution with an inclusive learning environment, who must daily demonstrate the desire for innovation, create equal conditions for learning and development of students with different nosologies and their comfortable stay within the school. According to O. Budnyk, the education manager must have professional readiness for the relevant activities, in the structure of which there are

11 Про освіту : Закон України від 05.09.2017 № 2145-VIII. URL: https://zakon.rada.gov.ua/laws/show/ (дата звернення: 02.01.2021). 
psychological, psychophysiological readiness, as well as scientific-theoretical and practical training as a basis for professionalism. The content of the professional readiness of a specialist is traditionally depicted in a professional profile - a generalized system of professionally determined requirements for the personality of a specialist. A.Kolupayeva in her work $^{12}$ defines the professional profile of a teacher-manager of education as an ideal model of a teacher, a sample, a standard, which presents the basic qualities of personality that he/she must possess; knowledge, skills, abilities necessary to perform pedagogical functions (in our case, management and organizational).

The managerial skills of the head should be determined by such components as the ability to understand the prospects of the PTE institution with a form of inclusive education, the ability to choose the right equipment and tools, anticipate developments, the ability to invest in the allocated budget and the ability to participate in projects to finance educational inclusion, cooperate with parents and teaching staff, increase their educational competence and constantly improve methods and forms of teaching and implement innovative methods.

For the successful implementation of the psychological and pedagogical cooperation of all participants in the educational process and the successful training of future professionals in the PTE institutions, each teacher must have professional pedagogical competencies that determine the level of preparation of the specialist (manager) for a particular activity. It is formed in the process of socio-pedagogical activities. During the formation of such activities in an inclusive environment, the question of the formation of inclusive competence arises. There is no clear definition of this competence, but, as M. Chaykovskyi notes: "A certain level of inclusive competence should be possessed by all participants in inclusion - from teachers and administrative staff to healthy students and support staff for qualified interaction in the educational process"13. The researcher considers inclusive competence, inclusive skills, and inclusive maturity as successive stages of personal professional growth of an employee of an inclusive educational institution, expressed by the following components:

- motivational, which is characterized by personal interest, attitude and a set of motives (social, cognitive, professional) to carry out certain professional activities in terms of inclusion of young people with special needs in the environment of healthy peers;

\footnotetext{
${ }^{12}$ Колупаєва А. А. Інклюзивна освіта: реалії та перспективи : монографія. Київ : САММІТ-книга, 2008. 270 с.

13 Чайковський М. Є. Інклюзивна компетентність як складова професійної компетентності суб'єктів навчально-виховного процесу. Педагогіка $i$ психологія професійної освіти. 2012. № 2. С. 20.
} 
- cognitive, which is defined as the ability to perform professional functions based on a system of knowledge about inclusive education and its role in its implementation, the experience of cognitive activity and the use of information in solving problems of inclusive education;

- reflective, which includes the ability to analyze and consciously monitor the results of their activities related to inclusive learning;

- operational, which represents the acquired methods and experience of performing professional tasks in the inclusive education, the ability to research and professional growth.

We believe that inclusive competence is the ability to choose methods, tools, and forms of providing information to students with special educational needs, to adequately assess the level of knowledge of students in the inclusive environment, to create teamwork in the study group among all participants. Inclusive competence of teachers belongs to special professional competences.

The high level of inclusive competence of the administrative and pedagogical staff of the educational institution will significantly expand and increase the result of the introduction of inclusion in its educational environment. In order to increase the level of inclusive competence, it is necessary for the administration of the PTE institution to create comfortable conditions for self-improvement. Teachers should be as creative and free as possible in choosing methods and forms of working with students with special educational needs, constantly discuss in collective meetings the pros and cons of inclusion, obstacles, and difficulties, which arise when students master skills and overcome all difficulties together. Of course, without proper cooperation of the psychological, pedagogical, and administrative staff of the educational institution, neither the teacher, nor the student, nor the PTE institution can achieve success.

Thanks to the same inclusive competence, teachers will be able to take into account the specifics of training students with special needs who have different nosologies. Scientist A. Kolupaeva gives some advice to the teacher on working with students who have certain disabilities in Children with Special Needs and Organization of Their Education, the scientific-methodical manual ${ }^{5}$. We will focus on the specifics of psychological and pedagogical activities with students with hearing impairments. Some students with hearing loss can hear but perceive certain sounds distorted, especially the initial and final sounds in words. In any case, the curator should read the student's medical history, consult with a teacher of the deaf, speech therapist, parents, teachers, who taught the student previously, to create and comply with special conditions of his studies. The method of teaching students with hearing impairments is based on visual perception of educational material: a teacher of the deaf should work in parallel with the teacher, and since students cannot listen and write at 
the same time, teachers should prepare adapted manuals, use multimedia techniques. It should be noted that the teacher of the deaf helps the teacher to provide personality-oriented direction of the educational process. Depending on the subject taught, the teacher submits the material in tables, diagrams, instruction cards. To consolidate the material the teacher develops didactic exercises and test tasks. A positive result of knowledge acquisition is the development by teachers of a whole course on the subject and its consolidation in the virtual learning space of the PTE institution. This form of teaching will create or improve a platform for distance learning, which is relevant in today's reality not only for students with special educational needs. Thus, all participants in the educational process and students have the opportunity to repeat the knowledge acquired in class, check their quality and, if necessary, improve. This form of knowledge acquisition can be used by masters of industrial training.

Very often students with special educational needs come to the PTE institutions not socialized or little socialized. This is due to the previous learning experiences of students. Therefore, teachers, and especially the curator of the group where students with special educational needs study, should create a democratic atmosphere and contribute to the formation of strong children's groups. All children, regardless of their state of health, should have the same rights and opportunities. A favorable environment encourages all children, regardless of their abilities, to research, initiative, creativity, which ensures successful learning and development. A sense of belonging is very important for children.

In its content, forms, and methods, education is not a constant, petrified phenomenon, because it constantly responds to new civilizational challenges, social realities, takes into account trends, prospects for human development, the national existence of the people. However, the renewal of educational practice often lagged behind the pace of civilizational development, social requirements for it. The most important feature of the modern education system is the coexistence of two strategies for organizing learning - traditional and innovative. Innovative learning is a process and result of educational and training activities that stimulates innovative changes in culture and social environment. Researchers of the problems of pedagogical innovation try to correlate the new in pedagogy with the useful, progressive, positive, modern, advanced. The idea of interactive technology is that the process of learning and cognition occurs with constant active interaction of all students; teachers and students are equal subjects of learning. Interactive learning promotes the formation of skills and abilities; development of life values; creating an atmosphere of cooperation, interaction; development of communicative qualities. This technology involves modeling life situations, the use of role-playing games, joint 
problem-solving. Interactive learning is the learning of dialogue, during which the participants of the pedagogical process interact with the aim of mutual understanding, joint solution of educational tasks, development of personal qualities of children.

Game learning technologies are such an organization of the educational process, during which learning is carried out in the process of including a student in the educational game. Students with special educational needs need such inclusion constantly. The purpose of educational games is to allow the student to self-determine, develop creative abilities, promote the emotional perception of the content of education.

The main purpose of the teacher is to create such situations for the development of students with special educational needs, which will allow each participant in the learning process to feel the joy of success, awareness of their abilities, faith in their strength. Therefore, the tasks to be set by teachers of the PTE institutions are: establishing an empathic relationship with a student with special educational needs; stimulating and supporting any positive manifestations in learning, communication, behavior; creating conditions under which the problems of the child's development do not interfere with the achievements in learning and acquiring a profession; identifying student's abilities and improving them during the learning process; helping the student's personality to grow in success, to make him/her feel the joy of overcoming difficulties; help the student understand that without effort nothing is given in life, it is necessary to make an effort all the time. The created situation of success becomes a starting point for changes in relationships with others, for further movement of the student up the stages of personal development. We need to choose the right words to address children to help them direct their thoughts and actions in the right perspective.

One of the conditions for the implementation of an individual approach is the use of non-verbal techniques of personal influence on the student, such as gestures, facial expressions, expressiveness of speech, gaze. The pedagogical technique of individual character helps to establish a special personal contact with the student and allows, in some cases, to inhibit the negative manifestations of behavior, and in others to stimulate him/her to work. Great attention should be paid to the organization of the system of lessons in such a way that each of them contributes to the involvement of students in work at different intervals, maintaining a stable cognitive interest and activity of each child. Different methods and visual aids need to be used to meet the needs of students with special educational needs.

The main vector of a modern teacher is the formation, development, and enrichment of both one's personal potential and future graduates of the PTE institution. And a mandatory component of the professional personality of the teacher is professional mobility, which helps to identify the creative 
activity of the student and develop him/her as a whole person who will live and work in the open European space.

According to A. Kolupayeva ${ }^{14}$, every teacher should create situations of positive social relationships of students. Through contact with peers, children develop emotionally and socially, they learn to live in harmony with people, they develop self-esteem.

Very often, socio-psychological and pedagogical barriers do not allow to develop not only the educational process but also destroy the positive microclimate in the group. The task of the teacher is to adjust all students of the group and their parents to a positive perception of children with special needs, showing optimism, the confidence of students with disabilities in the success of their studies, in a positive result, in supporting classmates. Such a positive atmosphere will help to overcome the difficulties of interaction and avoid many conflicts.

Parents should be an important part of the team for successful implementation and effective inclusive education in a PTE institution. For the cooperation of the head of the institution, pedagogical staff, and parents to be successful, each educational institution must determine the model of team activity: multidisciplinary, interdisciplinary, transdisciplinary. Multidisciplinary model: the child and the family are in the center of attention, but experts do not communicate with each other. There is no interaction between team members, their research and services are isolated. Interdisciplinary model: the focus is on the child and the family, but professionals are more connected to each other. Transdisciplinary model: the child and the family are in the center of attention and there is a strong relationship between them and specialists. There is also a mixed approach in which the child is considered comprehensively when all achievements and services are fully integrated.

The most suitable and effective for working with children with special needs is a transdisciplinary approach, in which there is an effective exchange of information among team members, there is a collective responsibility for the overall results. All team members must actively cooperate in the development of an individual curriculum for the child - a future specialist, a graduate of a PTE institution.

\section{CONCLUSIONS}

We can say that as a result of successful cooperation of psychological and pedagogical staff of a PTE institution and for successful training of

${ }^{14}$ Колупаєва А. А., Савчук Л. О. Діти з особливими потребами та організація їх навчання : науково-методичний посібник ; вид. доп. та перероб. Київ : АТОПОЛ, $2011.274 \mathrm{c}$. 
future specialists in inclusive education should be a team approach to all participants in the learning process, formed a common vision of phasing and training, determination of solutions in overcoming obstacles in the education of a student with special educational needs in a PTE institution, creation of universal design in the field of the inclusive learning environment. Priority is given to the formation and improvement of professional readiness of teachers, social workers, psychologists and other participants in the educational process through training, exchange of experience of teachers with many years of experience, analysis of inclusive education of the PTE institutions in other countries, training, and seminars. The main innovator and founder of such growth should be the head of the educational institution. We need to pay attention to the talents and abilities of students with special educational needs and help such students interact with other students. The main method of teaching students should be a person-centered approach. To do this, it is necessary to adapt the curriculum to the characteristics of the student and allow him/her to perceive information through sensory systems because if a student has hearing impairments, it is better to perceive educational information through video presentations. Having formed a distance course in their subject, each teacher will be able to confidently test the knowledge acquired by the student. After all, he/she created all the conditions for the educational process of students. With the successful organization of the educational process and its correct modification, the result of training and formation of practical skills of a graduate of a PTE institution will be high and he/she will be a competent worker in the labor market. And this is the most important goal of the pedagogical activity of the educational process participants in the PTE institutions.

\section{SUMMARY}

The research highlights the problem of implementing a strategy for the development of inclusion in PTE institutions in Ukraine and professional training of specialists in PTE institutions in the context of inclusive education. Successful learning outcomes and training of future specialists, graduates of PTE institutions in the conditions of inclusive education can be implemented only by teachers with professional training. Taking into account the psychological and pedagogical conditions of teaching and difficulties in teaching, the inclusive competence of teachers, psychologists, social educators is highlighted as a successful personal quality of each pedagogical worker. It is noted that for successful implementation and effective inclusive education in a PTE institution there should be cooperation with parents. The head of the institution and his pedagogical staff must determine the model of team activity. The problem of socialization and adaptation of students with special educational needs in the educational environment is considered. The result of 
the study is the division of models of teamwork, outlining a plan for the development of inclusion and psychological and pedagogical support of students in inclusive groups. The importance of professional training of teachers in the field of inclusion is noted.

\section{REFERENCES}

1. Концепція розвитку інклюзивної освіти : Наказ МОН України від 10.10.2010 № 912. URL: https://mon.gov.ua/ua/npa/prozatverdzhennya-kontseptsii-rozvitku-inklyuzivnogo-navchannya (дата звернення: 02.01.2021).

2. Про затвердження Порядку організації інклюзивного навчання у закладах професійної (професійно-технічної) освіти : Постанова КМУ від 10.07.2019 № 636. URL: https://zakon.rada.gov.ua/laws/show/ 636-2019-\%D0\%BF (дата звернення: 02.01.2021).

3. Ленів 3. П. Формування професійної готовності фахівців до роботи в інклюзивному освітньому просторі початкової школи. Обрії. 2018. № 2(47). С. 57-61.

4. Сисоєва С. О. Особистісно орієнтовані технології: сутність, специфіка, вимоги до проектування. Професійна освіта: педагогіка і психологія. 2003. № 4. С. 153-165.

5. Якиманська I. Я. Особистісно-оріснтована система навчання. Завуч. 1999. № 7. С. 22.

6. Будник О. Б. Педагогічний супровід інклюзивної освіти : навчальний посібник. Івано-Франківськ : Кушнір Г. М., 2019. 232 с.

7. Прядко Л. Готовність педагога загальноосвітнього навчального закладу до роботи 3 дітьми 3 особливими освітніми потребами як успішний фактор інклюзивного навчання. Матеріали Всеукраїнської науково-практичної конференції «Формування готовності педагогічних пращівників до роботи з дітьми з особливими освітніми потребами в умовах інклюзивного навчання». URL: http://roippo.org.ua/activities/ research/ conferenc.php/376/.

8. Демченко I. I. Готовність учителя початкових класів до роботи в умовах інклюзивної освіти: структура та діагностика : навчально.методичний посібник. 2014. 160 с.

9. Ленів 3. П. До проблеми моделювання процесу підготовки кадрів для роботи в інклюзивному просторі. Глобальні виклики педагогічної освіти в університетському просторі : матеріали III Міжнародного конгресу, м. Одеса, 18-21 травня 2017 р. С. 70-81.

10. Про створення умов щодо забезпечення права на освіту осіб 3 інвалідністю : Наказ МOH України від 02.12.2015 № 691. URL: https://ips.ligazakon.net/document/MUS3912 (дата звернення: 03.01.2021). 
11. Про освіту : Закон України від 05.09.2017 № 2145-VIII. URL: https://zakon.rada.gov.ua/laws/show/ (дата звернення: 02.01.2021).

12. Колупаєва А. А. Інклюзивна освіта: реалії та перспективи : монографія. Київ : САММІТ-книга, 2008. 270 с.

13. Чайковський М. Є. Інклюзивна компетентність як складова професійної компетентності суб'єктів навчально-виховного процесу. Педагогіка і психологія професійної освіти. 2012. № 2. С. 15-21.

14. Колупаєва А. А., Савчук Л. О. Діти з особливими потребами та організація їх навчання : науково-методичний посібник ; вид. доп. Та перероб. Київ : АТОПОЛ, 2011. 274 с.

\section{Information about the author:}

Denkovych N. A.,

Postgraduate Student at the Department of Pedagogy and Innovative Education Lviv Polytechnic National University 12, S. Bandera str., Lviv, 79013, Ukraine 